\title{
'Whoever does not leave his own shore behind will never discover anything new': Challenges for Islamic Religious Education in the European Context
}

\section{Introduction}

Education is one of the central themes of Islam. Numerous verses in the Qur'an and sayings by the Prophet Muhammad leave no doubt that education is one of the top priorities of the Islamic message. ${ }^{1}$ This assumption is shared by both Muslim and non-Muslim scholars (Bilgin, 1988; Günther, 2013, 360). The history of Islam also offers various examples that can be interpreted as indications of the special and, above all, religiously grounded high value of education and upbringing in Islam. Last but not least, the scientific and academic contributions of Muslims - especially up until the $12^{\text {th }}$ century - are an important indicator of the particular affinity of Islam with education. Next to education in general, religious education and upbringing - as in all religions - in the Islamic context played a crucial role right from the beginning. Right from the start, the Prophet paid special attention to education, and this contributed significantly to the acceptance and development of the Islamic message and to the promotion of education in general among Muslims (Günther, 2016).

The interest of the Muslim community in education, an interest that lasted for four hundred years, has decreased over time for various reasons. Even if it is not easy to determine the concrete reasons for this decline and the actual point in time that it occurred, it can be seen as part of the general stagnation in the 'Muslim world', which can be taken in general to have started at the beginning of the $13^{\text {th }}$ century. ${ }^{2}$ Since this time, despite various attempts, Muslim society has seldom succeeded in regaining its initial glory.

It was especially in the Enlightenment and the rapid technological progress driven by industrialisation in the West that made clear that the 'Muslim world' had not only lost its pioneering role in science, education, art, and culture towards the beginning of the $18^{\text {th }}$ century but also its connection to the modern

1 Cf. Q 2:266; 10:24; 13:3; 16:11; 19:13; 30:21; 59:2; Ibn Māğa, 1998, 214f.; At-Tirmidīi, 1996, 417. 2 The stagnation refers to the comparison with the period before the $13^{\text {th }}$ century and not to the prevalent view that, after the $13^{\text {th }}$ century, there were no theological or philosophical developments in the Muslim world or that the door to the interpretation of the Islamic law sources (ijtihad) was closed.

Ә OpenAccess. ( 2022 Zekirija Sejdini, published by De Gruyter. (cc) BY-NC-ND This work is licensed under the Creative Commons Attribution-NonCommercial-NoDerivatives 4.0 International License. 
world. A large part of the Muslim community was confronted with this bitter reality most recently through the colonisation of Muslim countries. As a reaction to the fact that the once inferior West had become superior in almost all-important areas, various reform movements in the 'Muslim world' aimed at - in addition to the liberation of their countries from the colonial powers - liberating the Muslim community intellectually as well from this desolate situation.

Looking back, these reform movements, which strove above all for changes in general and religious education, achieved very little. Instead of bringing the Muslim community closer to the developed world, these movements instead paved the way in the opposite direction, especially in the field of religious education. Some saw the solution to the crisis in which the 'Muslim world' found itself in the post-Enlightenment world primarily in rejecting the West and orienting itself to the original community of the prophet Muhammad. That was the view that prevailed. This led indisputably to an increase that orientation to the old and the aversion to more recent concepts of education - in particular those stamped by the West. Regrettably, this trend has continued into the present because of the current world political situation in wide parts of the Muslim world.

This attitude, which can be characterised as 'traditionalist', could be found among the majority of the Muslims who migrated to Europe at the beginning of the previous century in the labour migration at that time and was cultivated for a long time as their own and authentic religious approach in their new homeland. For a long time, this did not present a great problem for the Muslims, who lived on the margins of society, nor for the Europeans for whom the immigrants were 'invisible'. Finally, the Europeans were under the impression at first that this was a temporary phenomenon that would pass once the guest workers returned to their countries of origin.

Only the global political events at the beginning of this century, the continuous growth of the Muslim population in Europe, and the fact that the former labour immigrants had become an important part of society and a return to their home countries was no longer an option brought about change. Some political leaders became aware that the concepts of theology, education, and religious education at that time did not correspond either to the European understanding of education nor to the needs of Muslim students who had grown up in Europe. The integration of Islamic-theological studies in the local universities had thus become urgently necessary.

Given this new situation and the pressing need for a theological home for the Muslims living in Europe, the process of the integration of Islamic theological studies in domestic universities was set in motion, predominantly in Austria and Germany for several years. This initiative, which has in the meantime borne 
its first promising fruits, is a challenge for Islamic religious education. This challenge must not be underestimated, but it is also a major opportunity to develop an educational approach that, in the spirit of Islamic educational theory, views the context as a constitutive element of religious education.

This relatively new development in the process of the integration of Islamic theological studies in European universities, the beginnings of which (with a few exceptions) go back less than ten years, is in its early developmental phase at present. Here the long Islamic theological tradition is being integrated into a new, unfamiliar context. The question arises here as to how Islamic theological studies can succeed in finding an appropriate balance between the demands of the secular university and its own tradition to produce innovative approaches within this new arrangement that must meet the academic standards of the university on the one hand but can also be supported by its own tradition on the other (Sejdini, 2017a). Islamic theological studies cannot avoid this partly difficult process of discussion in the context of the secular university, to which other theologies are also subjected, if it is to be taken seriously in academic discourse. As is well known, academic discourse at a secular university is not simply a matter of managing theological knowledge but is concerned primarily with conceiving new approaches and promoting a continuous and impartial development (Schulze, 2010, 1).

We will return to this below. This essay takes as its starting point the conviction that, for the development of innovative approaches in Islamic religious education, a fundamental discussion - especially in theology - is needed, if the changes are to be more than superficial.

To give the best possible presentation of this theme, this essay is divided into three parts. In the first part, the various religious educational approaches will be described in order to situate the underlying religious educational model. In the second part, we will look at the particular context of Islamic theology and religious pedagogy in the European context. In the third and final part, we will discuss the most important challenges facing Islamic religious education to demonstrate what conditions must be filled to produce innovative approaches.

\section{Approaches to Religious Education}

A proper discussion of religious educational themes requires a disclosure of one's own models of religious education. Expressions, analyses, and proposals for solutions in religious pedagogy make sense only if the religious educational conception on which they are based is clear. That is why the various religious educational approaches will be briefly explored here. 
Current European research in religious education is dominated by two opposite approaches that encompass both religious education as a theory as well as religious didactics or religious education. These two approaches are, one, an approach more from the religious studies perspective and, two, a confessional approach. To illustrate these approaches, the model of religious learning developed by Michael Grimmitt (1981) and later picked up by the Dortmund religious educationist Bert Roebben can be used. This model speaks of levels "in religion" from an internal perspective of religion - "from religion”, and "about religion" from an external perspective (Roebben, 2011, 151).

The approach just cited, which focuses on learning about religions and has become established in England, for example, is characterised above all by its religious studies approach to religion or religious education. For this approach, the reference field of study is, in addition to pedagogy, not theology but religious studies. This model of religious education does not, of course, have any confessional connection, which means that in the schools, the content of the religious instruction, the religion teachers and pupils are not subject to any specific denomination in the educational context. Even if sympathy for this model is increasing, the confessional form is still being used both in religious education and in religious pedagogical research in German-speaking countries, especially Austria and Germany. This form does not leave out the 'in religion' aspect but connects it with the 'about' and 'from' levels. This understanding is distinguished from the previous one in that the confessional connection or orientation plays a crucial role here. Accordingly, this religious pedagogical approach goes beyond the so-called 'neutral' learning about religion. Thus, this approach represents a confessional religious education that the respective religious community is responsible for, is planned and given shape by its authorised teachers, and attended by homogeneous groups of students. Even if knowledge of other sciences, especially religious studies, is taken into consideration, the dominant reference field of study of this religious educational understanding are theology and education.

Aside from the possible advantages and disadvantages of the theological or religious studies approaches, which are, as is well known, the subject of debate, this essay is primarily concerned to point out the - in our case - partly also legally based general conditions and possible tensions that must be taken into account if a religious education programme, as I understand religious education is set up theologically. The tensions that arise do so because of the connection of confessionally understood religious education to the religious community, which often tends to take only the perspective of that community into consideration.

That is why it is necessary for Islamic religious educational research - and Islamic religious education - to explore a feasible path forward. On the one 
hand, this path must include dialogue with the religious community and collaboration with the other theological disciplines and on the other make compliance with the academic standards of research possible. Rolf Schieder views this structure - which is foreign to the classical Islamic tradition - as the only possibility

in which the secular, religiously neutral state can exercise influence via the sciences on the thinking and feeling of religious communities without abandoning the requirement of religious freedom. (Schieder, 2013, 17)

Whether or not it is viewed as such or as interfering with academic freedom, these considerations should show how much our attempts to develop innovative approaches in religious education are balancing acts and how reliant we are on external factors.

In addition to the tensions that also arise from its relation to its religious community, Islamic religious pedagogy is confronted with additional challenges, especially in the European context. We will explore these challenges in the following section.

\section{The Current Muslim Context in Europe}

The Muslim religious community, which now numbers 1.5 billion, is a community that encompasses different ethnic groups, nations, and cultural circles. The heterogeneous composition of the Muslim communities has led to country-specific imprints of Islam and various concepts of religious education. This diversity is also mirrored in the composition of Muslim communities in Europe. Many of the Muslims living in Europe have different ideas of what Islam is and what religious education or religious pedagogy can mean - as, for example, the recently published social-empirical study by Ayşe Uygun-Altunbaş (2017, 26f.) shows. Regardless of the plurality of differences, which we cannot go into here, there are nevertheless some theological commonalities that, with a few exceptions, are shared by a majority of Muslims and that are therefore important for Islamic religious education (Kolb, 2021a).

This does not refer to the personal attitudes of Muslims, which can be as diverse as those of the adherents of other religions. Rather, it refers to theological and religious-educational positions and attitudes that are still used, although they were developed in completely different contexts and periods and can be viewed as suitable for the education of modern people in only a limited way. The classical Islamic understanding of religious education, which is often transferred unreflectively in the guise of the authentic tradition, follows a paradigm 
that in essential areas contradicts an enlightened understanding of religious education oriented to freedom and human dignity. Admittedly, some fundamentals of this classical Islamic understanding are not unknown in the West, but they are viewed as outdated because of reforms in Christian religious education since the 1960s (Lachmann, 2013, 59). In contrast, for demonstrable and partly already mentioned reasons, Islamic religious education is still at the beginning of this process, which indeed includes many obstacles but is nonetheless inevitable (Tosun, 2015, 40). Thus, the following legitimate question arises: Can a religious tradition be made fruitful in religious education for people who are born and socialised in a completely different context, without presaging a 'clash of civilisations' or religions, as has usually been the case since Samuel Huntington?

The opposition of classical and contemporary paradigms for religious education can reveal the direction Islamic religious education should move if it is to meet the current understanding of religious pedagogy. Indeed, the classical paradigm is not specific to Islam but nevertheless widespread in Islamic religious education (ibid.). The classical or traditional understanding of religious education is characterised above all by being based on an objectivistic or essentialist epistemology. In this view, Islam is viewed as the only true faith, and, accordingly, the goal of religious education is primarily obedience to the religious content and to follow the tradition. The contemporary understanding of religious education is opposed to this traditional understanding because the former is based epistemologically on the orientation to the subject and thus perspectivist/constructivist approaches. As a result, with respect to methodology, the contemporary view operates based on the relation to the subject, interaction, and context. This understanding always entails a critical approach leading to the view that one's own faith is only one 'truth' among many, and thus the maturity and ability of people to make decisions is viewed as the supreme goal of religious education.

Assuming that the classical understanding of Islamic religious education is widespread, this opposition shows that a paradigm shift is needed if Islamic religious education is to make a positive contribution to both Muslims and the entire community in the current context. Even though there are no sharp lines of separation here and traces of contemporary approaches can be seen in the traditional understanding of religious education - which is not limited to one religion - and vice versa, the above distinction still holds for the most part.

Based on the current state described above, challenges in two areas in particular become manifest for the contextualisation of Islamic religious education in the contemporary context. These two areas influence the uniqueness of religious education: epistemology and the understanding of tradition in a fundamental way. 


\section{The Challenges for Innovation}

\subsection{Epistemology}

The question of the nature and limits of human knowledge is one of the central questions of human history. Various scholarly endeavours in early antiquity, especially in philosophy and theology, were devoted to this question. For our discussion, however, we first need to remember that, at the very least since Immanuel Kant, the notion that people could have a direct, unmediated knowledge of "things an sich" (Kant, 2010, 341) is no longer possible. Rather, knowledge is always mediated. Here, in this epistemological paradigm shift, the German physicist and mathematician Max Born sees 'the greatest blessing' to modern science. He writes:

\footnotetext{
I believe that ideas like absolute correctness, absolute precision, definitive truth, etc. are fantasies that should not be admitted to any science.... This easing of our thinking seems to me to be the greatest blessing that contemporary science has brought us. But belief in a single truth and to be its possessor is the deepest root of all evil in the world. (Born, 1965, 183)
}

This - from a contemporary perspective - apparently constructivist view of epistemology has found little purchase in Islamic theology, which plays a central role in Islamic religious education as a partner discipline. To the contrary: an attitude became established (in Christian theologies) in the wake of the Enlightenment that is stamped above all by the recognition of the autonomy of scientific or academic knowledge and the necessity of the claim of theology within academic discourse. And this attitude is seen and criticised as the relativisation of the truth claim and as bowing to pure rationality (Nasr, 1990, 17). Instead of questioning the truth content of its own statements and being admitted to the academic discourse to facilitate exiting from its "self-incurred tutelage" (Kant, 1999, 20, quoted in Perry et al., 1995, 56 f.), Islamic theology is currently dominated by approaches that are determined to avoid the 'Western path' and to promote a kind of Islamicisation of knowledge or the sciences in order to reconcile them with revelation (Uyanı, 2014). Parallel to these efforts, there is also an omnipresent tendency to view the Qur'an as the source of all knowledge in the natural sciences (Daud, 1989, 3f.). But how important and necessary this epistemological revolution is in theology and how much Islamic theology's participation in academic discourse depends on this can be seen in the following quote by Klaus von Stosch: 
Only because Christianity faced the challenges of such objections to faith by means of reason could it develop something like modern theology, which goes beyond the project of theology in antiquity and the Middle Ages in several respects. (Von Stosch, 2012, 78)

Instead of allowing the process of questioning oneself (and partly also) relativising one's own truth claims, wide tendencies in Islamic theology have implemented a self-immunisation. Stated simply, this self-immunisation continues entrenched thought and behaviour patterns as well as sacrosanct hierarchies through isolation, so that the oft-cited 'watering down of religion' that entails enormous difficulties, especially for the religious educational context can be avoided.

These difficulties are especially visible in contexts in which other theologies have not only completed this process of change but also took into account the results emerging from that in their theology. This happened in Christian theologies in the European context. As a concrete example of this, we could mention the development of the historical-critical method in biblical studies.

As indicated above, the unsolved question of the nature and limits of religious knowledge has, led to, among other things, a widespread acceptance in Islamic theology that theological statements can be articulated as universal truths only on the basis of their relation to the Qur'an as the authentic and unfalsified Word of God. Such statements thus constitute a type of alternative source for other sciences. What is interesting here is that, contrary to widespread belief, this attitude is not a classical phenomenon (Nusseibeh, 2016) but one found in modern Islam, under which the "rich Islamic history of ideas is buried" (Von Stosch, 2016b, 145f.) and suppressed by its own inability to deal with the achievements of the Enlightenment. This circumstance turns out to be a particular historical paradox because the European Enlightenment was based decisively on the importation of scientific and academic knowledge from Arabic countries in the Middle Ages and the early modern period (Cavallar, 2017).

This way of thinking, which views theology as a source of explanation for all the sciences, leads to an important problem that is closely connected with the view of the Qur'an as the Word of God or the understanding of revelation. The point here is that the Qur'an is not understood as a kind of orientation that has only limited application because of its linguistic and cultural imprint. Rather, it is viewed as a comprehensive and universal instruction and a communication of information about the world. This epistemological assumption often leads not only to viewing religious innovations as objectionable but as also contributing to the academic knowledge that is viewed as legitimate if they are apparently 'confirmed' by revelation or do not contradict it. 
This view, which has not lost any popularity among Muslim scholars, needs to be revised if Islamic theology and religious education is to be fruitful in the European context as well. This means the following. Even if it can be correctly assumed that, as an existential human need, religion needs no further justification, theological statements - especially those that are "cognitively relevant" (Schärtl, 2004, 164) - are subject to the same academic and scientific principles as all the other sciences, regardless of whether they can be traced back to revelation or not. This is a basic condition for the further development of Islamic theology and religious pedagogy and for their integration into academic discourse in the secular context. Without this fundamental encounter and a new orientation, this attempt to introduce religious innovations, especially in the area of Islamic religious education is not credible and is condemned to failure.

Beyond the fact that a perspectivist attitude in epistemology is a condition for innovations in theology and thus also in religious education, it also leads to the development of attitudes that belong in many respects to the basic conditions of religious education in a pluralist society. As Paul Watzlawick writes:

First, such a person would be free, for it would make him free to create his reality again and again and always anew. Second, such a person would be responsible in the deepest ethical sense, for whoever knows that he is the architect of his own reality, for whom the comfortable excuse of pointing to the constraints or guilt of other people is no longer available. And, third, this person would be conciliatory in the deepest sense of the word. (Watzlawick, 1992, 75)

With these considerations in mind, we now come to the second challenge for Islamic religious education, which is closely connected to the epistemological: the appropriate way to deal with the Islamic tradition.

\subsection{The Balance between Tradition and Innovation}

Common interpretations, doctrines, and experiences as well that can be characterised here as tradition are of special significance for the continuity of theology and religious education. Nothing arises in a vacuum but develops over generations. Nonetheless, traditions, especially theological ones, can also become major obstacles to innovation if they are not adequately understood and categorised. Especially religious minorities, such as Muslims in Europe, are inclined to emphasise their tradition to the religious maximum to guard against assimilation in order to thereby protect themselves and the tradition. A one-sided turn to tradition often happens in situations in which there is dissatisfaction with the current situation of one's own faith community. In such cases, there are 
often calls to get 'back to their roots' in the sense of a 'back to the future'; here it is believed that the solutions to current (and future) problems are found in the past - not as it actually was but as it is construed according to their own ideas.

Precisely there we encounter a problem that cannot be underestimated: it is not the tradition as such that constitutes a hindrance but the attitude that sees a historically conditioned and, in this form, the "best possible adaptation as the only one for ever" (Watzlawick, 1983, 28). According to Watzlawick, this view of tradition leads

to a double blindness: first a blindness to the fact that the adaptation in question is, through the passage of time, no longer the best possible one and, second, a blindness to the fact that, in addition to that one adaptation, there is always a whole series of other solutions or at least there is now. (Ibid., 29)

This kind of view makes a renewal in continuity with the tradition impossible. For this approach to tradition implies not only the assumption that there is only one "possible, permitted, rational, meaningful, and logical solution" (ibid.) but also that this premise "[should] never be questioned; one should never play around with this fundamental assumption" (ibid., 30). As a result, "the same 'solution' is resorted to all the more, and thus the same adverse conditions are created" (ibid.).

While not exclusively specific to Islam, this understanding of tradition has been widely received in traditional Islamic doctrines, especially in fundamentalist circles. It is, however, criticised not only by the Qur'an but also by some contemporary Muslim scholars. In addition to the criticism by philosophers like Fazlur Rahman and Mohammed Arkoun, the criticism by the Arabic thinker and philosopher Mohammed Abed Al-Jabri of this understanding of tradition is extremely fruitful. In his treatise Die Kritik der arabischen Vernunft (Critique of Arabic Reason), Al-Jabri locates a stagnation in the Islamic understanding of tradition that is characterised by a pure reproduction of the old, and because it is bound to constant repetition is not in a position to produce anything new. According to him, the contemporary solution consists in "overcoming this understanding of tradition that is embedded in the tradition in order to develop a modern understanding and a contemporary perspective of tradition" (Al-Jabri, 2009, Position 531). In other words, Al-Jabri proposes understanding the tradition "both as continuing and as going beyond its past forms" (ibid., Position 456) and thus being liberated from the classical understanding of tradition, which implicitly conveyed with it. What can help us here is a new understanding of tradition that "includes the present, that constantly renews, is examined, and criticised” (ibid., Position 872). 
In summary, it can be stated that a radical analysis of the nature of religious knowledge and the position of theological tradition is an indispensable condition for the development of an Islamic religious education that takes the Islamic tradition and the present context into account and aids in the cultivation of values that contribute to a pluralist and democratic society. Only in this way can an independently grounded Islamic religious education emerge that is not viewed as an application of theology but as generating theological knowledge from a perspective based on empiricism and education. It thus prevents theological statements from becoming ends in themselves. In the end, Islamic religious education cannot - from an educational viewpoint - be satisfied with passing on the ashes from generation to generation but needs to pass on the fire itself (Sejdini, 2016a).

It is not only religion that depends on such a theological and religious educational perspective coming out of education. Democratic and pluralist society as a whole is dependent on that as well. If we keep in mind that the secular democratic state, which is the guarantee of plurality, is based on conditions that it itself cannot guarantee (Böckenförde, 1976, 60), it becomes clear that a religious education programme is needed that can cultivate these values from an internal perspective. It is precisely there that we see the need to take the broader view or, in other words, to leave one's own shore behind in order to discover the new. 
